\title{
Heideggerian Ecofeminism
}

\section{Ecofeminismo heideggeriano}

DOI:10.12957/ek.2019.49544

Dra. Trish Glazebrook - Professor, School of Politics, Philosophy, and Public Affairs

patricia.glazebrook@wsu.edu Washington State University

The first paper I published on ecofeminism was an analysis of Heidegger's treatment of nature in his critique of science and technology (GLAZEBROOK, 2001). Now, almost two decades later, I continue to write as a Heideggerian ecofeminist on gender and climate change, especially adaptation and finance, with respect to African food security as well as on indigenous eco-defenders and -protectors, environmental justice, and sustainability with focus on the function of capital in the phallic order that is currently engineering mass extinction. In this chapter, I will trace the emergence and development of critiques of capital throughout this body of ecofeminist work and connect it with more recent research on Heidegger and economics.

\section{KEYWORDS Ecofeminism. Heidegger. Capital}

O primeiro artigo que publiquei sobre ecofeminismo foi uma análise do tratamento de Heidegger sobre a natureza a partir de sua crítica da ciência e da tecnologia (GLAZEBROOK, 2001). Hoje, mais de duas décadas depois, continuo escrevendo como uma ecofeminista heideggeriana sobre gênero e mudanças climáticas, especialmente sobre adaptação e finanças, em relação à segurança alimentar na África, assim como sobre ecodefensores e protetores indígenas, justiça ambiental e sustentabilidade com foco na função do capital na ordem fálica que atualmente engendra uma extinção em massa. Neste artigo, traçarei o surgimento e desenvolvimento das críticas do capital através do corpo do trabalho de ecofeminismo, conectando-o com pesquisas mais recentes sobre Heidegger e economia.

PALAVRAS-CHAVE Ecofeminismo. Heidegger. Capital 


\section{The Beginning}

As a child, growing up in Canada after we left England, I was what used to be called a 'tomboy' - I loved to be outside, whether it was $40^{\circ} \mathrm{C}$ or minus $40^{\circ} \mathrm{C}$. If I wasn't in school, I was as much as possible in the ravine behind our house, tobogganing in winter, climbing trees or building forts in the summer, and generally having a great time. I went inside only when my mother rang the Air-Raid Precaution Bell she found in an antique shop and gave to my father as a reminder of when he would ride his bike around the village to warn people to get to the shelter during the Second World War. I was number two of five sisters and a kind of surrogate son. When my father went to the Can-Am, a car race hosted annually in Edmonton, Alberta, he would take me. I was his helper when he landscaped our yard. If the cats brought home a half-dead mouse, the task of putting the poor thing out of its misery fell to me. In my 20s, I hiked the Rocky Mountains, often bush-whacking off trail or sleeping on glaciers where I would build a small rock-pile that sent the meltwater around the tent and not through it as we slept. Once we were stalked by a grizzly bear. But we knew how bears behave and recognized its warnings to keep moving. I grew up loving, trusting, and feeling completely at home in the 'great outdoors.'

At the same time, I was male-self-identified, not as a gender orientation but as someone who felt capable of interacting and competing with a privileged group that most people like me were excluded from. I was delighted to be 'exceptional,' i.e. both an exception and skilled in exceptional ways. I scoffed at the disciplines of femininity after a brief encounter with eye-shadow as a thirteen-year-old, and disdained pink, dresses, dolls, and anything I thought suggested a feminine stereotype. I had completely internalized misogyny. I think it might have started when I was nine and realized I would never be able to realize my dream of becoming a Jesuit. It suddenly hit me that having a vagina would limit my options. Naturally, I rejected feminism that I thought stood for all that was now against me. How are such self-misogyny and love of nature to come together as an ecofeminist not constantly at war with herself?

For me, it began with a Classics Professor at the University of Alberta, Dr. Rosemary Neilsen. She called me out for not being a feminist when we were reading Hesiod's Theogony. I dismissed it as irrelevant, but it was like a tiny sliver of wood in my finger that grew from irritation to inflammation that I could not get out. She always seemed frazzled, not quite prepared, frustrated, and easily aggravated. It took me a couple of decades to realize what gender politics and downright sexism she must have been subjected to every day in a department of aging male classicists. 
Then I went to graduate school in Toronto, Canada. My first assignment was teaching undergraduates in an Engineering Ethics course. I wondered why the $10 \%$ women's cohort was so uninterested in questions like, why are there so few women in engineering? I realized that they had the same 'exception' experience that I had. To admit that gender selection in mathematics and engineering is rooted in cultural bias, and that women in general are no less able by nature to succeed in STEM training than men, is to give up one's exceptional status as an atypical woman who is equal to men. Of course, women are not equal to men: women just as skilled are likely to find jobs harder to get, harder to keep, and inequitably compensated. Women can easily find themselves at the margins, inside but outside, and therefore subject to 'imposter syndrome,' the glass ceiling, and now the glass cliff-when a woman is hired to fix a long-standing, difficult problem and then tossed away when she is unable quickly to solve it. This insight into inequality has actually formed over twenty-five years of experience as a female philosopher, and I sometimes wonder what has happened in the careers of those women in their subsequent career development.

Strangely but strongly influential, however, in my time as a graduate student was an eccentric peer who held soirée-style dinners at which we were required to do readings together of Greek comedies, for example, and who was always turning up with what appeared to be random books that he was deeply invigorated by. Once he showed up with Vandana Shiva's Staying Alive and insisted I read a chapter about how eucalyptus plantations destroyed India's water table, that I later came to understood was a perfect storm of post-colonial systems of international aid, 'structural adjustment,' Green Revolution science-based solutions, and the urgency of scientists to obtain external funding to enable their career development. At the time, however, I had no context in which to situate these insights. It has nothing to do with Heidegger, Aristotle, and my unrelenting need to soak up the history of philosophy by drowning myself in it.

I did, however, take a feminism course - there was not much available in a time-slot convenient for my schedule. I don't remember much from it, though I remember that the professor was amazing. Nonetheless, I graduated and immediately found myself in a tenure-track position at Colgate University in a small town in up-state New York where I was hired as a Heidegger scholar, but obliged to teach feminism. This was the first recognition. Apparently, a vagina may preclude being a Jesuit, but it enables full qualification in something you know very little about, have never written about, have never said you are the least bit interested in, and have no training to teach. At last, I was forced to become a feminist, if for no other reason than to teach it responsibly. 
As I taught feminism, I also learned much about the mid-1990s, small town America, university experience for students and faculty. I learned that feminists are really called 'femi-Nazis.' Date rape is probably because a 'girl' is angry that she has been dumped. 'Real women' don't say yes, but 'real men' don't take no for an answer. That is, everything is rape but nothing is rape. It's ok not to let women into fraternities because women have sororities that are the same and function as an excellent service industry for the fraternities. But don't try to organize a women-only meeting, even if it's a Speakout on sexual assaultthat's discrimination. The fraternities were established in 1813 while women were only first admitted to the university in 1970. So sororities are off campus and highly regulated by the town. For example, a sorority can only have three guests present at any time unless they apply and are granted a permit. Fraternities are also off campus technically, but directly across the road from the campus in a line known as 'Frat Row.' The 'cops' don't go there because what happens there is a university issue. The university doesn't go there because it's not their jurisdiction. So if you want to sell pot, you should live in a frat. Also, this means that frats have the best parties because they can host as many people as they want with all the drugs and alcohol they want, and they bring in great bands. Some frats have 'proof-of-conquest' rituals during 'rush' - the application period for membership - in which 'pledges,' i.e. hopeful applicants, must collect underwear (in particular, 'panties') or an earring from a 'townie' 'girl' in order to qualify for admission. One sorority gets each pledge to stand in her underwear during rush while 'sisters' circle her holding permanent markers to record on her body any excess 'fat' that she must get rid of to qualify for entry. If a new pledge to a frat, chosen to remove an 'exotic dancer's' panties with his mouth during a party of a hundred or more frat boys celebrating new members, bites her vagina, she will be pulled out by her security and taken to a hospital for a prophylactic shot of antibiotics. Women who object to any of this are probably old, ugly, and jealous of how hot the sorority girls are.

As faculty, I also learned that it is not my place to ask the first question of a visiting speaker because my male colleague does that. If I wait and later ask a question, that male colleague, who has no $\mathrm{PhD}$ and has published nothing, will stage-whisper, 'well that's just bullshit,' loudly enough for everyone to hear while I am in the middle of my question. Later that day, I will be told to be more respectful to him. If a senior faculty Latina woman is bullied in a department meeting and speaks to defend herself, she will be asked why she is so defensive. If you say, because it seems like she is being attacked, you will probably lose your job. If you give a talk at a frat house at their invitation called 'Why I 
Hate Frats,' you will probably lose your job. They will likely be surprised that someone might be offended to be a priori excluded from their organization, and they may also be concerned about date rape and develop anti-date rape policies and protocols for their parties, e.g. designated drivers who work in teams to keep women safe, a poster campaign. You will probably still lose your job. If you support a female job candidate from India, you will probably lose your job because your colleague who teaches Buddhism and leads a white Christian church says that he knows 'these Indians,' and 'they are not to be trusted.' If you support a Latino job candidate, you will probably lose your job. The central administration of the University will hire him, despite department objections, and give him your job.

That's how I became a feminist: brute force; public insult; trauma; unfair, radically differential treatment; punishment for refusing to practice the disciplines of femininity - obedience, silence, and deferral. If I wanted a job, I should have no views on anything. Rather, I took what I saw to be the lesser of two evils and became a feminist. I had read the literature because I was obliged to teach it. And my head exploded: I am not the only one treated in these ways; it is not just misogynistic men but institutional bias (though there are also some awful men); feminism is not just justice for me or for women, but for everyone living in a world run by a phallic order that overwhelmingly benefits men, mostly white cis men, at the expense of the rest of us. I vomited up the internalized misogyny and drank the feminist Kool-Aid.

\section{The Middle}

The 'middle' for me is a time of discovery of the global South, of understanding the limited representation of woman's needs globally in Eurocentric feminism and the need to overcome these limits. In this section, I describe my journey to Karen Warren's ecofeminism through philosophy of nature and build from her influence on my Heideggerian ecofeminism. Her account of logics of domination affirmed my reading of Heidegger's essence of technology as exploitative of nature.

While at Colgate, I had a generous and kind, senior, male colleague who was Department Chair. He suggested that I develop a course in the philosophy of nature as this flows naturally from my reading of Heidegger but is a broader and more attractive topic than just Heidegger for students as environmental 
issues continue to come again to the forefront throughout the 1990s. Indeed, a central assessment of Heidegger's philosophy of science in my work is that he understands the (Eurocentric) intellectual history of the West to be a series of interpretations of nature. For Aristotle, nature (physis) is what moves of its own accord, where movement mean development. So for example, a puppy becomes a dog, not a tree. Natural entities, if they survive, follow directed growth toward a goal (telos) in fulfillment of what they are. So things in nature have their own purpose: to become fully what they are. People intervene in that process by taking material from nature and crafting it into an artifact.

In medieval thinking, however, it is divine teleology that drives growth: natural entities follow a plan created by a god who is a divine craftsman. So nothing is any longer understood as its own master moving toward its own goal, but all is reduced to what Aristotle took to be production, i.e. creation by an artist, albeit a divine artist in the medieval, Roman Catholic account. Laplace, as a modern scientist, however, subsequently declares god an 'unnecessary hypothesis' (Ball 2003 [1908]), which leaves natural entities with neither their own telos as in Aristotle's account, nor the divine purpose of medieval theology. Nature is thus purposeless (ateles) and readily available for appropriation into human purposes.

In fact, the essence of technology is famously understood by Heidegger to be a modernist, reductive interpretation of nature as nothing more than resources (Bestand, usually translated as 'standing-reserve' but much more intelligible as 'resource') standing by for human use, i.e. having only instrumental value. I have elsewhere documented this as Heidegger's argument in detail (GLAZEBROOK, 2000) and developed the part of that argument involving Galileo's mathematization of nature in his claim that the universe is a book written in the language of mathematics (HEIDEGGER, 1987/1967; GALILEO, 1957) to argue further that this mathematization prepares natural entities for appropriation not just to human ends but more specifically to the profit-driven purposes of capital (GLAZEBROOK, 2019). I have thus built the argument beyond Heidegger, but the course I developed in philosophy of nature using Heidegger's 'once-upon-a-time' of the intellectual history of the West also took me well outside the Heideggerian account.

For reasons unclear to me now, that course drew into the work of Karen Warren. In fact, as noted above, Colgate first admitted women in 1970. I was hired there in 1994. I pointed out to the Dean that 1995 was the $25^{\text {th }}$ anniversary of admitting female students and proposed that I invite Karen Warren to come 
and deliver some talks in celebration of that milestone. She agreed, and indeed Karen came. To prepare the students in the Philosophy of Nature course, I assigned a series of her essays. Again, my head exploded. I have never left behind he account of logics of domination, in which a binary is introduced, e.g. man/ woman, man/nature, reason/emotion, and then ranked so one is superior; that superiority is then used to justify the privileged superior's exploitation of the other, or her argument in defense of narrative voice as epistemological method (WARREN, 1990). This is not surprising given how closely her account of logics of domination align with Heidegger's analysis of the essence of technology as exploitative of nature and people. Narrative voice as a legitimate method also opened an epistemology for me that exceeded the model of ahistorical truths, scientific objectivity, and representational thinking that Heidegger so strongly repudiated while giving me little alternative in his epoch-based analysis of truth as historically situated.

Warren talked instead of her relationship with a mountain that she could not climb by conquering but by engaging in a relationship with it, a kind of dialogue (WARREN, 1990), and swimming with dolphins that only came to her when she gave up trying to control the outcome (WARREN, 2000, 120-21). This resonated well my experiences backpacking in the Rockies, where nature is, experientially, a seething buzz of movement that made me consider my place in it, especially in the food chain, but also showed both care in providing ways for me to meet my needs but also indifference to my survival. I concluded from those experiences that it is up to me to pay attention to what is going on around me because, if I can work with - rather than against as conqueror - natural processes, I can thrive. For example, looking at and listening to my environment taught me not to pitch then tent, or even stop for lunch, below a glacier that might at any moment drop an ice break-off. Nature 'talks' and thriving (that starts with survival) means listening. These ideas of a different relation to nature than that determined by the essence of technology appear in Heidegger's discussions of Gelassenheit, of 'letting beings be' and 'openness to the mystery’ (HEIDEGGER, 1992/1966), but I don't think I could have understood these ideas without my experiences in the wilderness and Warren's descriptions of non-dominating relationships with natural entities.

Warren also had strong arguments for taking empirical data seriously. Nature is a feminist issue, she argues (WARREN, 2000), because understanding women's relation to nature and impacts on women when their environment is compromised helps to understand women's oppression, subordination, and domination. I have argued that environmentalists must be feminists for at least six reasons: 
1. women's health suffers more than men's in consequence of environmental degradation, and women's bodies, especially their reproductive functions, are more susceptible to environmental toxins;

2. most of the world's farmers are women who often grow not for market but to feed their family, so climate adaptation programs, for example, cannot support food security if they do not understand and meet women farmers' needs;

3. environmental degradation increases women's lived experience of poverty, e.g. deforestation and desertification oblige women to work harder for more hours to meet family daily living needs if they must walk further to collect wood for heating and cooking, and water for daily use;

4. women are marginalized but nonetheless significant players in environmental reform and have much wisdom to contribute to sustainable policy and practice;

5. women's groups have achieved successes in places where men's groups have failed, e.g. the women of the Deccan development Society in India were able to improve livelihoods for the rural poor through environmental remediation, seed saving, and other practices, after men's groups failed; and,

6. environmentalists' concerns about population can only be addressed justly by addressing family planning in terms of women's health, education and livelihood.

(GLAZEBROOK, 2015)

Accordingly, women's health, poverty, and ability to provide food security are deeply entangled with ecosystem health. Environmental movements that fail to account for women's situations and respond to their needs therefore cannot succeed and are working against their own agenda. 
At the same time, Warren's discussion of the Chipko women in India (WARREN, 2000) as an example of why empirical understanding of women's concrete situations is important drew me back to Shiva's Staying Alive by providing an initial context to start understanding Shiva's work after what had been a largely theoretical study of ecofeminism against a background of Heidegger's critique of science and technology. Shiva exploded my head again by arguing that 'development perceives poverty only in terms of an absence of Western consumption patterns, or in terms of cash incomes and therefore is unable to grapple with self-provisioning economies' (SHIVA, 1993, 289). Assumption that all cultures want to follow the global North's development path suggests that every culture should strive toward that reality, though many cultures have sustained epistemologies, ontologies, and economies in their communities for generations. 'Subsistence economies' remains, however, a disparaging term, though families in many places across the world draw heavily on unpaid labor. Capital economies cannot function without the support of largely female, unpaid, labor. This was my first recognition that feminism is an economic issue as I came to understand the feminization of poverty but also women's strength and resilience in operating in long-standing, alternative economies based on care-practices.

In the meantime, however, during my time at Colgate, I was living in a small town with little going on after six o'clock in the evening that wasn't over-run by frat boys. So naturally, I joined a band as hand drummer and percussion. In 2001, after leaving Colgate (for reasons discussed above) for nearby Syracuse, NY, I accidentally became apprenticed to a master-drummer from Ghana who had just himself relocated to Syracuse. Through him, I met a women's group, Beyond Boundaries, that was raising funds to take to a women's organization in northern Ghana. I began organizing drum and dance sessions for the group and in 2002 went with them to deliver the funds. I learned how hard the women work to grow food and raise their family, how resilient they are in the face of a changing climate, how happy the children are with perhaps only one set of clothing as they roam the village free all day long with the goats and other farm animals. I went home and immediately began researching agriculture, policy, women's issues and all I could find out about Ghana while applying for grant money. In 2007, I went back to the tiny village, sixteen hours by bus from the capital city, for eight months with my four-year-old son.

During those months, I learned that everything the ecofeminists said about women's poverty, education, agriculture, marriage, and situation, as well as their strength, and the persistent social inequalities they are subjected to, was in fact the case. In the rainy season, roughly April to September, they had experienced 
a drought followed by a catastrophic flood just a few days before we arrived, that for many women destroyed their crop and perhaps also their mud-house. They have no irrigation but depend on the rains, so now had no way to feed their family until the next growing season. They all could explain to me in intricate detail how climate change works, its impacts on rain and their crops, and what they are doing to try and adapt. They are changing their crop selection. Typically, they grow groundnut (peanuts) that are a great source of protein. The nuts grow underground, and if the plant does not get enough rain consistently after planting, the leaves above ground continue to grow well but the nuts do not. At the end of the season, when the top is pulled up, there are no nuts in the roots and an entire season of crop care is wasted. Another traditional crop is millet, a grain that is high in protein and calcium and excellent for women who are pregnant or lactating, and growing children. But inadequate rain means too small a yield to feed the family through Harmattan (a cold, dry season from late September or so into early January in which winds from the Sahara blow down dust that looks like fog or smoke in the distance) and the dry season (also known as the hot season until the rainy season brings cooler temperatures and turns brown to green). Given unpredictable rain patterns, the women cannot rely on these traditional crops and instead grow drought-resistant rice. Rice has virtually no nutritional value and provides only carbohydrates that lead to kwashiorkor, in which the belly is bloated by water retention while the limbs are like twigs because there is no protein to grow muscles. Protein deficiency can also impair mental health (starvation can induce psychosis), and cause edema (swelling), organ failure, wasting and shrinkage of muscle tissues, and weakness of the immune system. In other words, women are sacrificing their nutritional base simply to put something in the child's mouth to stave off starvation (GLAZEBROOK, 2015a).

At the same time, Ghana discovered oil off-shore in 2007 that was first produced in 2011 to be transferred to Norwegian tankers and transported elsewhere for refining. Oil revenues are intended to improve the lives of Ghanaian citizens by creating wealth. But African resource wealth is well known to suffer from the blessing-or-curse curse paradox. Long-standing research on resource wealth elsewhere indicates the negative impacts of sudden resource wealth, known as 'the Dutch disease' because of a decline in manufacturing in the Netherlands in 1977 following discovery of a large natural gas field. The wealth created by the gas find pushed out other industries. This concept continues to be widely applied in post-resource discovery economic analysis. Oil has moreover been identified elsewhere in Africa as a curse rather than a blessing because of its role in corruption, conflict and environmental devastation (GLAZEBROOK and KOLA-OLUSANYA 2011; GLAZEBROOK and STORY 2012). Beyond 
these risks, fossil fuel driven climate change is affecting crops. Women grow $70-87 \%$ of what goes into the national food basket, depending on who you ask (GPRS I 2003, 75; SWC 2010, 109). these women are experiencing significant crop loss in northern Ghana that is causing nutritional deficiency and a hunger crisis. Ghana has a wealth-creation policy concerning oil that is actually in conflict with women farmers' needs as food security providers. Likely, the benefits of oil development will accrue to some while others, in this case woman farmers and their family, will suffer the costs of climate change.

\section{The End}

In this section, I show how Vandana Shiva further globalized my understanding of women's relation to their environment as food producers, the feminization of poverty, and post-colonial impacts of technoscience in the phallic order on women's traditional agricultural practices. She also taught me that ecofeminism is an economic issue.

As has been shown above, Heidegger's account of the essence of technology as a logic of resource exploitation, and his analysis of the mathematization of nature, allow a further analysis of capital as a system of exploitation in which nature and other human beings are reducible to an exchange value. At a global level, the U.S. plays a role as middle-man in the global economy. For some time, that economy was pinned down by the Eurodollar market in which money was stored outside the U.S. in U.S. dollars, over which the U.S. itself had no control. By 1985, it was estimated that of the $\$ 1.668$ trillion USD in circulation, $75 \%$ were likely Eurodollars outside control of the U.S. Federal Reserve (VATTER and WALKER, 1995). This was a problem for the U.S. because it challenged its role as middle-man in the global economy, a role that allowed strong influence on that economy. Oil, however, has restored that power as it comes to underwrite the global economy: the significant role of oil in the post-Eurodollar global market was made starkly evident, for example, when the U.S. shale oil boom, i.e. fracking, that began in 2012 affected OPEC's capacity to control oil prices that in turn strongly influence the global economy. Fracking has allowed the U.S. to continue to control the global economy through the Petrodollar instead of the Eurodollar. Yet the big-economy, global players are not necessarily prepared to continue to be managed economically by the U.S.

The recent murder of Iranian General Soleimani has in fact been described as a 'worrying picture' of 
a desperate U.S. lashing out at a world turning its back on a unipolar world order in favor of the emerging multipolar...The Petrodollar ensures that the U.S. dollar retains its status as the global reserve currency, granting the U.S. a monopolistic position from which it derives enormous benefits from playing the role of regional hegemon...To threaten this comfortable arrangement is to threaten Washington's global power. (PIERACCINI, 2020)

China plays an increasing role in the global economy that has strained its trade relationships with the U.S.. Venezuela, Russia, and Iran hold a portion of the majority of the world's oil and gas reserves, have 'elevated relations' with China, and support the emerging multipolarity that China and Russia wish to consolidate, allegedly to grow the Eurasian supercontinent peacefully. The rest of the majority of oil and gas reserves are in Iraq, Qatar, and Saudi Arabia. Saudi Arabia could be swayed to the China-Russia solidarity for both military and energy reasons. And Iraq and Qatar are both still disturbed by 'numerous strategic errors in the region' made by the U.S., from invasion of Iraq in 2003 to, more recently, Yemen, where forty drone strikes in less than a month killed hundreds, including children, in March 2017, in an attack that became even less justifiable because it was allegedly based on shaky intelligence. Concerning Iraq, the 2003 U.S. invasion was based on fabricated intelligence that bin Laden, who mater-minded 9/11 was in Iraq. There is substantial reason to believe that in both the 2003 invasion of Iraq and the 2020 killing of Soleimani, a message was actually being sent by the U.S. that it is not prepared to relinquish its unipolar authority over global economics.

What I have just laid out is a game of thrones in which the U.S. is increasingly facing a global power struggle. As oil and gas company executives and members of parliaments and governments reap massive profits, millions of people lose virtually everything. An international power struggle is underway in which environment, violence, and food and water insecurity are deeply inter-linked in global economic system that depends on fossil fuels. Beyond the military threat that this power struggle needs and enables, oil and gas production and the burning of fossil fuels is creating the greatest harm the human species has faced in known history through destruction of food systems, water systems, and habitable ecosystems. The struggle for power in that economic system, and the consequence of focus on that struggle rather than acknowledging the need for 
immediate transition away from fossil fuels, is already causing massive human suffering in agricultural collapse in Africa, unprecedented fires in Australia and on the U.S west coast, and mass flooding on several continents. What is also clear is that overwhelmingly the beneficiaries of the fossil fuel industry are the men in whose hands this industry lies.

The impact of this extremely lucrative industry on the planet is now enough to be visibly recorded in the fossil record. Hence the planet is argued to be now in the Anthropocene, the geological time period in which human being (Anthropos) is having a visible impact greater than any other. As an ecofeminist, I argue however, that we live not in the Anthropocene but the Androcene. That is, the world we live in has been shaped by a history of gendered logics of domination, in which technoscientific mobilization of global conquest transforms 'sources of regeneration and renewal of life...into inert and fragmented matter, mere 'raw material' to be processed into a finished product' (MIES and SHIVA, 1993, 26). Mechanistic, reductionist logics create ecological crisis when 'organic processes and regularities and regenerative capacities are destroyed' (SHIVA, 1998, 24). Technoscience implements knowledge-praxes of manipulation and destruction because techne-based epistemology has inverted knowledge through denial of ontologies that conceive nature as nurturing, regenerative process. For example, biology kills in the dissection room in its attempt to understand life.

In women's care work globally, growing food is mostly women's responsibility. Agricultural biotechnology manipulates nature to increase yield, but displacing nature's cyclical processes with profit-generating harvest destroyed soil and water systems in India (Shiva 1988). Replacing traditional agriculture with Green Revolution approaches that favored fertilizers, monocultures, and mechanization and were not 'based not on cooperation with nature, but on its conquest' (SHIVA 1991, 29). These practices disrespected both nature's processes and people's knowledge: local knowledge 'was displaced ... [by] experts breeding a small set of new varieties' (Shiva 1991, 44-45). Systems that had functioned for centuries within nature's limits to ensure renewability of plant life and soil fertility were replaced by systems that considered natural limits to be simply constraints that could be overcome by science (MIES and SHIVA, 1993, 28). Non-technoscientific knowledge-systems were excluded as superstition, myth, folklore, and 'old wives' tales' (CURTIN, 1999). Women's long-standing agricultural practices learned over generations were considered 'the 'shackles of the past', (SHIVA, 1991, 34-5). This technoscientific cult of the expert that undermines scientific literacy and reduces the human capacity for knowledge humans 
to know, is irrational on its own account because it 'rejects the belief systems of others ... without full rational evaluation' (SHIVA, 1988, 26). Heidegger likewise argues that technology takes itself to be the only truth and 'drives out every other possibility of revealing' (HEIDEGGER, 1977, 31).

In the phallic order of the Androcene, women's subsistence economies are marginalized by capital that is for the most part under the control of men, while poverty is experienced disproportionately by women in the feminization of poverty, even in the global North. Capital's denial of nature's gynocentric reproductive function privileges production. Hence Shiva argues that the 'relationship between reductionism, violence and profits is built into the genesis of masculinist science, for its reductionist nature is an epistemic response to an economic organization based on uncontrolled exploitation of nature for maximization of profits and capital accumulation' (SHIVA, 1988, 23). This is the connection between the phallic order, capital, and logics of domination in which people, other lifeforms, and ecosystems are disposable while Big Oil reaps massive profits at their expense.

In short, Karen Warren and Vandana Shiva enabled me, as a Heideggerian, to develop my ecofeminist analyses into all-out critique of logics of capital in the phallic order and to make argument for gynocentric logics of care based on Warren's method of narrative voice and practice of listening to nature rather than conquering it, and Shiva's account of the cyclical, generative, life-affirming nature of gynocentric logics and practice in contrast with scientific enablement of profit system in phallic logics of domination. Capital economies train people to believe that the purpose of human existence is the individual accumulation of private wealth. Gynocentric care economies aim instead at thriving for people, all life, and ecosystems. It is through this care logic that I am reconciled as an ecofeminist who is comfortable being an ordinary woman who will never be equal in the sexist, still misogynist context of philosophy departments where, despite having offices on three continents and out-publishing my colleagues annually, I am 'managed' at best like a whacky aunt to be humored, but more often like I am just difficult, a bitch, and a trouble-maker to be avoided, as if I chose to be a feminist.

When I first came to where I am now as Director of the School of Politics, Philosophy, and Public Affairs, I would attend Dean's meetings with my nineteen colleagues in leadership positions in the other College units. Only one was a woman. She had chaired her department for years, was older than me, and dyed her hair blue. Every once I while, she would glare around the room as 
if challenging us all, and blurt out something fairly outrageous, for example, 'well, that's just the bee's knees,' or 'soon we'll have to start whacking them on the head.' All my male colleagues would lean slightly forwards with the same smile, look at each other knowingly, and then go back to business. She is actually really smart but has done an excellent job of demonstrating to our male colleagues that she is not a threat to them. And then I think of the women of Standing Rock, of the indigenous women of the Amazon basin, of Berta Caceres, and all the environmental and land protectors who dare to be a perceived threat despite actual threat to their life, of which some have been taken, usually by ex-military hired assassins, and the men, and many people of all kinds today resisting white power, the mega-rich, pipelines, and irreparable damage to people, animals, ecosystems and the planet caused by of phallic logic of capital for the sake of profit. I see the change is coming - that is why the capitalists are fighting back so hard. Because we are strong.

\section{Recebido em: 08.03.2020 | Aprovado em: 25.03.2020}

BALL, W. W. Rouse. [1908]. A Short Account of the History of Mathematics. New York: Dover Press, 2003.

CURTIN, Deane. "Recognizing women's environmental expertise". Chinnagrounder's Challenge: The Question of Ecological Citizenship. Bloomington, IN: Indiana University Press, 1999.

GALILEO. The Discoveries and Opinions of Galileo, tr. Stillman Drake. London: Anchor Books, 1957.

GLAZEBROOK, T. "From physis to nature, technê to technology: Heidegger on Aristotle, Galileo and Newton". The Southern Journal of Philosophy 38(1):95$118,2000$.

“Heidegger and ecofeminism”. Re-Reading the Canon: Feminist Interpretations of Heidegger, eds. Nancy Holland and Patricia Huntington. University Park, PA: The Pennsylvania State University Press, 221-251, 2001.

"Ecofeminism without borders: The power of method". Environmental Ethics for Canadians, ed. Byron Williston, 2nd ed. Oxford, UK: Oxford University Press, 164-171, 2015.

"Climate adaptation in the global South: Funding women's farming". Contemporary Perspectives on Eco-Feminism, eds. Mary Phillips and Nick Rumens. London: Routledge, 111-131, 2015a.

"Heidegger and economics: Withdrawal of being in capital". Studia Culturalogica (Divinatio): 
New Ways of Contextualizing Heidegger, 47:7-21, 2019.

GLAZEBROOK, T.; KOLA-OLUSANYA, Anthony. "Justice, conflict, capital, and care: Oil in the Niger Delta”. Environmental Ethics 33(2):163-84, 2011.

GLAZEBROOK, T.; STORY, Matt. "The community obligations of Canadian oil companies: A case study of Talisman in the Sudan". Corporate Social Irresponsibility: A Challenging Concept, eds. Ralph Tench, William Sun and Brian Jones. Bingley, UK: Emerald Group Publishing, 231-61, 2012.

GPRS I (2003). “Ghana Poverty Reduction Strategy: 2003-05”. International Monetary Fund: IMF Country Report No. 03/56, March 6 2003. Washington, DC: IMF Publication Services.

https://www.imf.org/en/Publications/CR/Issues/2016/12/30/Ghana-Poverty-Reduction-Strategy-Paper-16390. Accessed 8 March 2020.

HEIDEGGER, Martin. Discourse on Thinking, trs. John M. Anderson and E. Hans Freund. New York: Harper \& Row, 1966.

.What is a thing, Tr. W. B. Barton, Jr. and Vera Deutsch. Chicago: Henry Regnery Company, 1967.

. “Die Frage nach der Technik", Vorträge und Aufsätze. Pfullingen: Verlag Günther Neske, 9-40, 1977.

.Die Frage nach dem Ding. Tübingen: Max Niemeyer Verlag, 1987.

.Gelassenheit. Stuttgart: Verlag Günther Neske, 1992.

MIES, Maria; SHIVA,Vandana. Ecofeminism. Lon- don: Zed Books, 1993.

PIERACCINI, Federico. "The deeper story behind the assassination of Soleimani". Strategic Culture Foundation. World: Middle East. 8 January 2020.

https://www.strategic-culture.org/news/2020/01/08/ the-deeper-story-behind-the-assassination-ofsoleimani/

SHIVA, Vandana. Staying Alive: Women, Ecology, and Survival in India. London: Zed Books, 1988.

.The Violence of the Green Revolution. London: Zed Books, 1991.

."The Impoverishment of the Environment: Women and Children Last". In: Ecofeminism, eds. Maria Mies and Vandana Shiva. Atlantic Highlands, NJ: Zed Books, 1993.

SWC (2010). "National Reports-Ghana: MDGs remain elusive". Social Watch Coalition. ghana2010_ eng.pdf. http://www.socialwatch.org/node/12082. Accessed 8 March 2020.

VATTER, Harold G.; WALKER, John F. eds. History of the U.S. Economy since World War II. London, UK: Routledge, 1995.

WARREN, Karen. "The power and the promise of ecological feminism". Environmental Ethics 12 (2): 125-46, 1990.

Ecofeminist Philosophy: A Western Perspective on What It Is and Why It Matters. Lanham, Maryland: Rowman \& Littlefield, 2000.

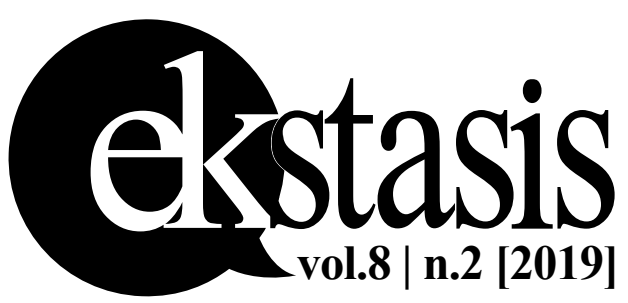

